\title{
Disintegrated Impact of Trade Openness on Income Inequality: Empirical Evidence from Bangladesh
}

\author{
Munem Ahmad Chowdhury (Corresponding author) \\ Department of Economics, Comilla University, Kotbari, Cumilla 3506, Bangladesh \\ Tel: 880-183-693-3939Ｅ-mail: munemahmad@gmail.com
}

Hafsa Rahman Nijhum

Department of Economics, Comilla University, Kotbari, Cumilla 3506, Bangladesh

Tel: 880-175-396-3789_E-mail: rahman.hafsa208@gmail.com

Kazi Mohammed Kamal Uddin

Department of Economics, Comilla University, Kotbari, Cumilla 3506, Bangladesh

Tel: 880-191-229-5675 E-mail: kamaleco1@yahoo.com

Received: May 11, 2021 Accepted: May 31, 2021 Published: June 8, 2021

doi:10.5296/ber.v11i3.18728 URL: https://doi.org/10.5296/ber.v11i3.18728

\begin{abstract}
There have been many studies on the relationship between trade and income inequality, but very few of them have distinguished the idea of trade by export and import. For this reason this study is conducted to see how the income inequality of Bangladesh get impacted with the presence of import and export separately. ARDL bound test is used to inspect whether they possess long run relation with income inequality for the period of 1975 to 2016. Thereupon export has been found to be widening the income gap in the long run. Though import improves the situation by abating the gap, it is not significant enough. Besides that other imperative macroeconomic variables are used to condense the omitted variable bias and their outcomes akin to the theory for developing country aspect. Furthermore, models like FMOLS, DOLS and CCR are used for ensuring the robustness of the result and other diagnostic tests support the validity of the result. Moreover policies related to labor welfare need to be set in a manner so that minimum wage allows a worker to lead a healthy life which will help keeping him or her productive. In addition, correspondent authority should frame the policies to
\end{abstract}


diversify the export sector to give the opportunity to small entrepreneurs a chance to enter by providing the convenient environment.

Keywords: Trade, Income inequality, Time series Models, ARDL, Bangladesh

\section{Introduction}

After adopting liberalization policy in 1980, almost every nation gradually moves toward to open their trade. Because of globalization, it has become an important issue of debate for the policy makers to discuss how the level of income distribution is affected with gradually opening up trade in Bangladesh. Trade openness means removal or imposing less restriction over trade like subsidies, tariff and quota, in order to integrate all domestic market into international market, exchange technology, ensure investment and reduce dead weight loss across the world .Secondly, trade openness equalize the factors price around the world according to factor price equalization theorem (Mahesh, 2016; Anderson, 2005). On the other hand, income distribution involves how a country allots their total income among their population. In reality, income can be diverted from person to person because of variation in some factors which is personal factors like birth status, education level, technological adaption, skills, economic factors such as demography, employment rate, inflation, urbanization and also political factors like transparency, nepotism and democracy (Muhibbullah \& Das, 2019). Thus income inequality creates in a nation or region, which can be measured by Gini coefficient ranging from 0 (when there is no inequality exist means everyone get same income) to 1 (when entire income goes to mere one person). It's a strong belief that openness widens the market from local to international, supply more cheap raw materials and quality products, which reallocates employment to new sectors, resulting smooth economic development in developing country. According to $\mathrm{H}-\mathrm{O}$ theorem, lower tariff and less restriction of trade barriers provide an opportunity to an emerging nation to specialize their production in which their comparative advantages lies. As unskilled labor is available and cheap in developing nation it is expected that by opening up trade new productive sectors will be emerged which may reduce income inequality by involving more unskilled labor in those sectors. For example, openness may help to expand textile and garments industries which increase the demand for female labor especially in a developing country like Bangladesh which attempts to remove both gender and wage inequality (Gourdon 2007; Calderon \& Chong, 2001).But this theory is challenged by Aradhuyla et al., (2007), Munir et al., (2013), Barro (2000) and Arif \& Saeduzzaman (2015). They opined that wage gap between rich and poor can be increased in a labor abundant nation because of trade liberalization and if the country has a liberal government. So, it has become a burning issue to check the background of income inequality and export and import amount data of Bangladesh. After liberation war in 1971, Bangladesh adopted a trade policy called import substitution to provide safeguard to infant industry for attaining self-sufficiency. But this policy didn't work efficiently because of poor infrastructure, bad product management and lacking of skilled persons (Siddique, 2019). So, in 1980 Government of Bangladesh focus on new policy named export promotion, set up EPZ to manufacture goods and also attracting foreign investor (Arif \& Saeduzzaman, 2015). After liberalization of trade policy the volume of export and import drastically changed with the passage of time. In 1972 import (\%GDP) and export (\%GDP) 
amount was only $13.73 \%$ and $6.29 \%$ which almost doubled to $24.74 \%$ and $16.64 \%$ in 2016 (WDI). According to Bangladesh Bureau of Statistics (BBS) (2016), the income share of the poorest $10 \%$ of the household population received 1.01 percent of the total national income in 2016 which was 2 percent in 2010. In comparison, the richest 10 percent of the population owned 38.16 percent of the national income in 2016 which was 35.84 percent in 2010. This means the rich are growing richer in income and wealth day by day. This sharp rises of income inequality have a long term impact on society, community and economy which give a threat to achieve the 10th goal of Sustainable Development Goal (SDG), which is reduction of inequality within and among countries (Muhibbullah \& Das, 2019). So, the aim of this study is to examine the relationship between income inequality and trade with the appearance of influential macroeconomic variable of Bangladesh by analyzing the data from 1975 to 2016 and what are the reasons behind it.

\section{Objectives of the Study}

The general objectives of the study is, how income inequality behaves in the long run when trade is dissected into export and import to obtain the individual impact of both export and import in the context of Bangladesh by using empirical analysis, but some specific objective will be conducted like;

1. To demonstrate the short run behavior among aforementioned variables

2. To find out how income inequality interact with the other influential macro variables.

3. To identify the factors which may cause downing the income inequality.

\section{Review of the Literature}

Analyzing unbalanced data of five South Asian country, from 1990-2016, Khan et al., (2020) found that, income inequality is declining with greater openness of trade, by standardizing the livelihood of mass people. He also accused the overflow of FDI \& increasing secondary education percentage, because these create disparity between skilled and unskilled labor. Demand of skilled labor increases in an industry because of receiving more FDI and people who receive more education grave those opportunity and raise their income more than less educated. Because of openness, different type of inequality such as gender inequality, spatial inequality and income inequality has been created by affecting factors price opined by Anderson (2005). Greater openness generates lower inequality in response to favorable shocks to export demand and terms of trade. It can be more effective policy to reduce inequality in low income countries reported by Lim \& MacNelis (2014). The conventional theory of Globalization was challenged by Arif \& Saeduzzaman et al., (2015). They showed strong evidence that in Bangladesh trade reduce income of labor by pulling too much supply of labor, where remittance influences income inequality in a negative way. Meschi \& Vivarelli (2009) has investigated 65 developing countries over the 1980-1999 periods and observed that higher income grosser countries may degenerate the income distribution of developing one. In order to reduce income inequality in those nations, Jaumotte et al., (2013) suggested to expand export of agricultural products. Because most of the labors of developing countries produce agro based goods. By investigating unbalanced data from 1976-2002 of 68 
countries Gourdon (2007) find that liberalization of trade create difference between skilled and unskilled, rising demand of skilled, increases wage deviation. By analyzing time series data from time span 1980-2010, Amjad (2015) concluded that there is an inverse and very significant relation between trade openness and inequality, because trade, mainly import reduces the price of domestic products of Pakistan. So, mass people can utilize their existing income in a very convenient way. Also workers' remittance and FDI play a vital role for reducing income diversity. Besides there have been reviewed a body of empirical literatures on this aspect which are represented in the Table 1.

Table 1. Literature review

\begin{tabular}{|c|c|c|c|c|}
\hline Author & $\begin{array}{l}\text { Area of study } \\
\& \\
\text { Time span }\end{array}$ & Methodology & Major findings & Elasticity \\
\hline $\begin{array}{l}\text { Mahesh } \\
(2016)\end{array}$ & $\begin{array}{l}\text { BRICS Nations } \\
(1991-2013)\end{array}$ & GMM estimation & $\begin{array}{l}\text { Trade openness explained in two } \\
\text { different ways as trade volume and } \\
\text { import \&export. As nation of } \\
\text { BRICS are labor abundant, opening } \\
\text { up trade could not bring benefit for } \\
\text { all sectors like agriculture which } \\
\text { creates larger gap of income. }\end{array}$ & Positive \\
\hline $\begin{array}{l}\text { Aradhyula et } \\
\text { al., } \\
(2007)\end{array}$ & $\begin{array}{l}60 \text { countries } \\
(44 \text { developed } \\
\& \\
\text { developing } \\
\text { countries }) \\
(1985-1994)\end{array}$ & $\begin{array}{l}\text { Pooled OLS } \\
\text { (2 stages) }\end{array}$ & $\begin{array}{l}\text { Where corruption and land locks } \\
\text { are inferior and secondary } \\
\text { education is ensured, income } \\
\text { discrimination is lessened by } \\
\text { opening up trade. }\end{array}$ & $\begin{array}{l}\text { Positive } \\
\text { (Developing } \\
\text { country) } \\
\text { Negative } \\
\text { (Developed } \\
\text { country) } \\
\end{array}$ \\
\hline $\begin{array}{l}\text { Munir et al. } \\
(2013)\end{array}$ & $\begin{array}{l}\text { Pakistan } \\
(1972-2008)\end{array}$ & $\begin{array}{l}\text { Maximum } \\
\text { likelihood } \\
\text { co-intregation, } \\
\text { VECM }\end{array}$ & $\begin{array}{l}\text { In Pakistan, import is larger than } \\
\text { export which forms consumer } \\
\text { goods enhancing more inequality. } \\
\text { Remittance and interest rate also } \\
\text { increases wage gap. }\end{array}$ & Positive \\
\hline $\begin{array}{l}\text { Barusman \& } \\
\text { Barusman } \\
(2017)\end{array}$ & $\begin{array}{l}\text { USA } \\
(1970-2014)\end{array}$ & OLS & $\begin{array}{l}\text { More openness (basically export) } \\
\text { and more FDI create more income } \\
\text { to upper class people who are } \\
\text { skilled and capital oriented. } \\
\text { Besides inflation reduces income of } \\
\text { rich people and opposite scenery is } \\
\text { true for government spending. }\end{array}$ & Positive \\
\hline $\begin{array}{lr}\text { Khan } \quad \& \\
\text { Bashir }(2011)\end{array}$ & $\begin{array}{l}\text { India } \\
(1970-2009)\end{array}$ & $\begin{array}{l}\text { ADF, Johansen } \\
\text { Co-intergation, } \\
\text { Granger causality } \\
\text { test, ECM }\end{array}$ & $\begin{array}{l}\text { Due to trade liberalization, import } \\
\text { supposed to increase more in India } \\
\text { which reduced the production of } \\
\text { domestic substitute goods and } \\
\text { decreased demand for labor which } \\
\text { created unemployment and resulted } \\
\text { in widening income gap. }\end{array}$ & Positive \\
\hline $\begin{array}{l}\text { Nath \& Al } \\
\text { Mamun } \\
(2004)\end{array}$ & $\begin{array}{l}\text { Bangladesh } \\
(1959-2000)\end{array}$ & $\begin{array}{l}\text { ADF, VAR, } \\
\text { Sensitivity } \\
\text { Analysis }\end{array}$ & $\begin{array}{l}\text { In Bangladesh, new sectors } \\
\text { appeared by importing raw } \\
\text { materials by opening up trade } \\
\text { which started to reduce income gap } \\
\text { by creating employments. }\end{array}$ & Negative \\
\hline $\begin{array}{l}\text { Oloufade } \\
(2012)\end{array}$ & $\begin{array}{l}39 \text { developing } \\
\text { country } \\
(1984-1999)\end{array}$ & $\begin{array}{l}\text { LSDVC(least } \\
\text { square dummy } \\
\text { variable correction }\end{array}$ & $\begin{array}{l}\text { Trade openness reduced income } \\
\text { inequality where there is less } \\
\text { conflict risk and vice versa. }\end{array}$ & Positive \\
\hline
\end{tabular}




\begin{tabular}{|c|c|c|c|c|}
\hline & & estimator), GMM & & \\
\hline $\begin{array}{l}\text { Daumal } \\
(2013)\end{array}$ & $\begin{array}{l}\text { India \& Brazil } \\
(1980-2004)\end{array}$ & $\begin{array}{l}\text { ADF, PP test, } \\
\text { VAR, } \\
\text { ECM }\end{array}$ & $\begin{array}{l}\text { Because of coastal zone, southern } \\
\text { part of India got more benefit in } \\
\text { importing raw materials. So, large } \\
\text { industries became south centric and } \\
\text { provided more employment } \\
\text { opportunities than north. Hence } \\
\text { regional income inequality was } \\
\text { created. When Brazil moved } \\
\text { toward to industrial } \\
\text { decentralization, industry spreading } \\
\text { in whole nation and increased } \\
\text { export of agro based product, } \\
\text { reduced income gap. }\end{array}$ & $\begin{array}{l}\text { Positive (India) } \\
\text { Negative } \\
\text { (Brazil) }\end{array}$ \\
\hline $\begin{array}{l}\text { Bukhari \& } \\
\text { Munir (2016) }\end{array}$ & $\begin{array}{l}11 \quad \text { Asian } \\
\text { country } \\
(1980-2014)\end{array}$ & Pooled OLS, IVLS & $\begin{array}{l}\text { As most of the developing } \\
\text { countries are labor abundant, } \\
\text { opening up trade can create an } \\
\text { opportunity to export more labor } \\
\text { based product. As a consequence, } \\
\text { the trend of declining income } \\
\text { inequality supports HOS theorem. }\end{array}$ & Negative \\
\hline $\begin{array}{l}\text { Adams } \\
(2008)\end{array}$ & $\begin{array}{l}62 \text { developing } \\
\text { country } \\
(1985-2001)\end{array}$ & $\begin{array}{l}\text { Seemingly } \\
\text { uncorrelated } \\
\text { regression (SUR) }\end{array}$ & $\begin{array}{l}\text { Despite opening up trade, a nation } \\
\text { which holds the intellectual } \\
\text { property rights strictly to itself } \\
\text { can't alleviate the income disparity. }\end{array}$ & Positive \\
\hline $\begin{array}{l}\text { Aigheyisi \& } \\
\text { Egbon } \\
(2020)\end{array}$ & $\begin{array}{l}\text { Nigeria } \\
(1981-2015)\end{array}$ & $\begin{array}{l}\text { ADF, PP test, } \\
\text { Johansen } \\
\text { Co-integration, } \\
\text { DOLS }\end{array}$ & $\begin{array}{l}\text { Foreign buyer felt more interest in } \\
\text { investing new sector in Nigeria } \\
\text { when trade was liberalized, which } \\
\text { involved more people in work } \\
\text { place, lessened income gap. }\end{array}$ & Negative \\
\hline
\end{tabular}

Source: Authors' compilation

As per previous studies we came to see that the most of researcher used trade openness (ratio of the sum of export and import to GDP) as prime and sole indicator, but the individual impact of import and export on income inequality is infrequent in previous literature. Besides that, paper like Nath \& Mamun, (2004) and Arif et al., (2015) used different variable to define income inequality, i.e. GDP per capita as a proxy and also some influential macroeconomic variable wasn't included which may cause biasness in formulating the result. So this study is conducted for fulfilling the gap. In this study, an index of income inequality has been used where there is no intermittency in the data set for the determined study period and effect of trade will be shown through segmentation as well as finding out if there is any long run relationship among them and highlighting the role of other macroeconomic variables in overcoming the curse of income inequality.

\section{Data and Methodology}

To examine the main objective, this study aims to analyze annual time series data covering the period of 1975 to 2016 for Bangladesh. Description and sources of data are given in table 2. Based on the suggestion, taken from the previous study, this study incorporates the relationships as following functional form. We have utilized log linear modelling in this study 
by converting variables in their natural logarithmic form. More comprehensive and reliable result can be found by this than the simple linear modelling (Shahbaz \& Rahman, 2010).

$$
I N Q=f(E x p, I m p, P c G, R e m, U r, E x g)
$$

Econometric model

$$
\text { Gini }=\beta_{0}+\beta_{1} \operatorname{Exp}+\beta_{2} \operatorname{Imp}+\beta_{3} P c G+\beta_{4} \operatorname{Rem}+\beta_{5} U r+\beta_{6} E x g+u_{t}
$$

Table 2. Data description

\begin{tabular}{|l|l|l|}
\hline Variable & Definition & Sources \\
\hline Gini & $\begin{array}{l}\text { Estimate of Gini index of inequality in equivalized (square } \\
\text { root scale) household disposable (post-tax, post-transfer) } \\
\text { income. }\end{array}$ & $\begin{array}{l}\text { Standardized World Income } \\
\text { Inequality Database (SWIID) (See } \\
\text { (Solt, 2016). }\end{array}$ \\
\hline Exp & Exports of goods and services (current US\$) & World Development Indicator (WDI) \\
\hline Imp & Imports of goods and services (current US\$) & WDI \\
\hline PcG & GDP per capita (current US\$) & WDI \\
\hline Rem & Personal remittances, received (current US\$) & WDI \\
\hline Ur & Urban population & WDI \\
\hline Exg & $\begin{array}{l}\text { Official exchange rate (Units of Bangladeshi Taka per US\$, } \\
\text { period average) }\end{array}$ & WDI \\
\hline
\end{tabular}

Source: Authors' compilation

Most of the time, economic variables which are time series are not stationary. Stationarity means mean, variance and covariance of a series are time invariant (Gujarati et al. 2012, pp-783). So, the stationarity level of the variable are needed to be measured. If the variable is non-stationary, it has unit root problem and if it is taken in consideration for further analysis it would give spurious result. For selecting appropriate model for time series analysis, checking stationarity level of variables is a precondition. Among various unit root test, Augmented Dickey Fuller (ADF) (Dickey and Fuller, 1979) test is one of the most popular unit root test. The regression form of ADF is;

$$
\Delta Y_{t}=\beta_{1}+\beta_{2} t+\lambda Y_{t-1}+\sum_{i=1}^{m} \alpha_{i} \Delta Y_{t-i}+\varepsilon_{t}
$$

$Y_{t}$ indicates vector of all variables that are included in the study. $\Delta, t, \beta_{1}, \lambda$ and $\varepsilon_{t}$ represent difference operator, deterministic trend, drift parameter, unknown parameter and white noise error term. The above regression is estimated by $\tau$ (tau) statistics under two hypotheses. Null hypotheses is, there is a unit root problem, $\mathrm{H}_{0}: \lambda=0$. Alternative hypothesis is there is no unit root problem or the series is stationary, $\mathrm{H}_{1}: \lambda<0$. If calculated absolute $\tau$ (tau) statistics is greater than absolute critical $\tau$ (tau) statistics which is provided by Mackinnon (1991), null hypothesis is rejected (Gujarati et al., 2012). It means there is no unit root problem or the series is stationary. If calculated absolute value doesn't exceed the critical one, the series is not stationary. Before proceeding to the co-integration, it is essential to ascertain maximum lag length for the study model (Bahmani-Oskooee \& Brooks, 2003). In that case VAR lag length selection criterion helps us by taking the lowest possible value among Akaike information criterion (AIC), Schwarz information criterion (SC) and Hannan-Quinn information criterion (HQ). 
In order to detect the long run relations among the variable, co-integration test needs to be conducted. Several co-integration approaches are introduced with various assumptions. Some of them are Johansen-Juselious, Maximum likelihood, Engle-granger and so on. However, Auto regressive distributive Model (ARDL) has some advantage on this conventional co-integration method. The key advantage is it can be applied on the regressors irrespective of their order of integration. In simple words, it is not a problem for it, either the variables being integrated at level, I (0) or first differences, I (1) or mixture of both (Pesaran et al., 2001) (Note 1). Besides that, it provides efficient estimators even if the sample size is small. It may remove autocorrelation and endogeneity problem. By this approach, individual can get short run dynamics as well. Another merit of this analysis is it can take different optimal lags for different variables. Optimal lag length is determined by the smallest value among AIC, SC and HC. AIC is used. This method contains few steps. Firstly, ordinary Least Square method is used for estimating the equation mentioned below to carry out the dynamic relations.

$$
\begin{gathered}
\Delta \operatorname{Gini}_{t}=\alpha_{0}+\sum_{i=1}^{k} \delta_{1 i} \Delta \operatorname{Gini}_{t-i}+\sum_{i=0}^{k} \delta_{2 i} \Delta \operatorname{Exp}_{t-i}+\sum_{i=0}^{k} \delta_{3 i} \Delta \operatorname{Imp}_{t-i}+\sum_{i=0}^{k} \delta_{4 i} \Delta P c G_{t-i} \\
+\sum_{i=0}^{k} \delta_{5 i} \Delta \operatorname{Rem}_{t-i}+\sum_{i=0}^{k} \delta_{6 i} \Delta U r_{t-i}+\sum_{i-0}^{k} \delta_{7 i} \Delta E x g_{t-i}+\phi_{1} \operatorname{Exp}_{t-1}+\phi_{2} \operatorname{Imp}_{t-1}+ \\
\phi_{3} P c G_{t-{ }^{-} 1}+\phi_{4} \operatorname{Rem}_{t-1}+\phi_{5} U r_{t-1}+\phi_{6} \operatorname{Exg}_{t-1}+\mu_{t}
\end{gathered}
$$

Where, $\Delta$ is the difference operator, $\delta \mathrm{s}$ and $\phi \mathrm{s}$ are the short run and long run coefficients for respective variables and $k$ is the optimal lag length. $\mu$ is the stochastic error term which is generally white noise in nature. Then based on F-statistics, ARDL bound test brings out the joint hypothesis for all exogenous variables. Null hypothesis is that there is no long run relations among the study variable, $\mathrm{H}_{0}=\delta_{1}=\delta_{2}=\delta_{3}=\delta_{4}=\delta_{5}=\delta_{6}=\delta_{7}=0$. The alternative hypothesis is $\mathrm{H}_{1} \neq \delta_{1} \neq \delta_{2} \neq \delta_{3} \neq \delta_{4} \neq \delta_{5} \neq \delta_{6} \neq \delta_{7} \neq 0$, long run relations exist there. The F-statistics should be compared with two critical bounds, upper bound and lower bound, which was given by Pesaran et al. (2001) and was improved later by Narayan (2005) for small sample. If the calculated F statistics value is greater than the upper bound, null hypothesis will be rejected. If the calculated value is less than lower bound, null hypothesis will be accepted. If it falls within two bounds, the result will be inconclusive. When the co-integrating relation is confirmed, long run coefficient will be watched out. Lastly, an unrestricted error correction model will be formed to estimate the short run dynamics.

Unrestricted error correction framework

$$
\begin{aligned}
\Delta \text { Gini }_{t}= & \alpha_{0}+\sum_{i=1}^{k} \delta_{1 i} \Delta \operatorname{Gini}_{t-i}+\sum_{i=0}^{k} \delta_{2 i} \Delta \operatorname{Exp}_{t-i}+\sum_{i=0}^{k} \delta_{3 i} \Delta \operatorname{Imp}_{t-i}+\sum_{i=0}^{k} \delta_{4 i} \Delta P c G_{t-i} \\
& +\sum_{i=0}^{k} \delta_{5 i} \Delta \operatorname{Rem}_{t-i}+\sum_{i=0}^{k} \delta_{6 i} \Delta U r_{t-i}+\sum_{i-0}^{k} \delta_{7 i} \Delta E x g_{t-i}+\theta e c t_{t-1}+\mu_{t}
\end{aligned}
$$

Here, $e c t_{t-1}$ represents error correction term and $\theta$ is its coefficient. The coefficient should be negative and highly significant. It tells that how quickly the error correction mechanism converges to the equilibrium point.

Now it is important to check the validity of the results after receiving them according to the study plan, because it better highlights the transparency of a study. Among various diagnostic test, Breusch-Godfrey LM test, Breusch-Pagan-Godfrey test, Jarque-Bera test and Ramsey 
RESET test have been examined for checking whether our estimated model and parameters are suffering from serial correlation, heteroscedasticity, non-normality and misspecification problem. CUSUM test stands for Cumulative Sum of the Recursive Residuals. CUSUM and CUSUM square test are useful to find out instability of parameters. If the calculated cumulative sum plot lies within the two 5\% critical lines, it is considered as stable (Brown, Durbin, and Evans, 1975).

To check robustness of long run coefficients estimated from ARDL, equation 2 has been reassessed by Fully Modified Ordinary Least Square (FMOLS), Dynamic Ordinary Least Square (DOLS) and Canonical Cointegrating Regression (CCR) which were provided by Phillips and Hansen (1990), Stock and Watson (1993) and Park (1992). FMOLS is a semi-parametric approach which corrects the problem of long run serial correlation by transforming the parameter and data in a single cointigrating relation (Priyankara, 2018). On the other hand, CCR estimates cointegrating vectors using only the data transformation. DOLS is a parametric method which uses leads and lags in the model to find out the long run coefficient (Priyankara, 2018; Masih \& Masih, 1996). All these models can deal with endogeneity, autocorrelation and small sample problem (Sapuan \& Roly, 2020).

\section{Results and Discussion}

For checking stationarity level, ADF test is used which is discussed in table 3 . We have run the test for both intercept and trend. For the case of Gini, PcG and Ur, null hypothesis have been rejected at their level. It resulted in there is no existence of unit root problem at their level. So they are integrated at $\mathrm{I}(0)$. But other variables are not stationary at their level as probability value of their $\tau$ statistics is not significant and not greater than the critical values. Then they need to be checked with their first differenced value. After differencing their value in first order they became stationary. So they are classified as I(1). So there is a mixture in their level of integration.

Table 3. Unit Root test

\begin{tabular}{|c|c|c|c|c|c|}
\hline \multirow[t]{2}{*}{ Variable } & \multicolumn{2}{|l|}{ Intercept } & \multicolumn{2}{|c|}{ Trend and Intercept } & \multirow[b]{2}{*}{ Inference } \\
\hline & Level & $1^{\text {st }}$ difference & Level & $1^{\text {st }}$ difference & \\
\hline Gini & -2.434314 & -2.795401 & $-3.894211^{* *}$ & $-4.674417^{* * *}$ & $\mathrm{I}(0)$ \\
\hline Exp & 0.069827 & $-9.761604^{* * *}$ & -1.949842 & $-9.636436^{* * *}$ & I(1) \\
\hline Imp & 0.188306 & $-7.668850^{* * *}$ & -2.328923 & $-7.732630^{* * *}$ & $\mathrm{I}(1)$ \\
\hline $\mathrm{PcG}$ & 0.917704 & $-9.693579^{* * *}$ & $-4.137731^{* *}$ & $-9.306865^{* * *}$ & $\mathrm{I}(0)$ \\
\hline Rem & -2.296233 & $-8.182126^{* * *}$ & -2.251830 & $-8.038611^{* * *}$ & $\mathrm{I}(1)$ \\
\hline $\mathrm{Ur}$ & -1.534271 & $-3.435654^{* *}$ & $-5.621139^{* * *}$ & -2.759928 & $\mathrm{I}(0)$ \\
\hline Exg & -2.924426 & $-4.413873^{* * *}$ & -0.901662 & $-5.331560^{* * *}$ & $\mathrm{I}(1)$ \\
\hline \multicolumn{6}{|c|}{$* * * 1 \%$ significance level } \\
\hline
\end{tabular}

Source: Authors' calculation using Eviews 


\section{Mll Macrothink}

Business and Economic Research ISSN 2162-4860 2021, Vol. 11, No. 3

After determining their individual integrating level, next step is to select appropriate co-integration model. As we have combinations of both integration levels, ARDL model is suitable for this purpose. But before that we have to navigate the maximum lag length. One rule of thumb is, as the study have used annual time series data, VAR lag length selection method should be run for maximum 1 or 2 lag (Wooldridge, 2010). Another rule of thumb is the criterion which poses lowest possible value should be selected for lag length. However AIC is superior and efficient for small sample. So in table 4, AIC has the lowest possible value (-31.42793) among all criterion which indicates lag level 2 and it will be applied in the co-integration approach.

Table 4. Lag length selection

\begin{tabular}{|l|l|l|l|l|l|l|}
\hline Lag & LogL & LR & FPE & AIC & SC & HQ \\
\hline 0 & 254.7224 & NA & $7.17 \mathrm{e}-15$ & -12.70371 & -12.40514 & -12.59658 \\
\hline 1 & 625.7356 & 589.8158 & $5.03 \mathrm{e}-22$ & -29.21721 & -26.82850 & -28.36016 \\
\hline 2 & 717.8447 & $113.3651^{*}$ & $7.09 \mathrm{e}-23^{*}$ & $-31.42793^{*}$ & $-26.94911^{*}$ & $-29.82097^{*}$ \\
\hline$*$ indicates lag order selected by the criterion \\
LR: sequential modified LR test statistic (each test at 5\% level) \\
FPE: Final prediction error \\
AIC: Akaike information criterion \\
SC: Schwarz information criterion \\
HQ: Hannan-Quinn information criterion \\
\hline
\end{tabular}

Source: Authors' calculation using Eviews

Then ARDL bound test is investigated to check the status of co-integration. Maximum lag length was determined by AIC earlier and now ARDL estimates $(\mathrm{P}+1)^{\mathrm{k}}$ different models regarding variables' individual optimal lag within this maximum lag length (Note 2). Among them, ARDL $(1,1,1,2,0,0,1)$ is more parsimonious. So based on this F statistics is calculated and it is known that $F$ statistics is very sensitive to the lag length. In table 5, null hypothesis of nonexistence of long run relation has been rejected as the value of $F$ statistics is greater than upper bound at $1 \%$ level. So there is a long run relation among our dependent and independent variables.

Table 5. ARDL Bound test result

\begin{tabular}{|l|l|l|l|}
\hline Null hypothesis: No long-run relationship exist & \multicolumn{3}{|l|}{ Critical Value Bounds } \\
\hline F statistics Value- 17.90104 & Significance & I0 Bound & I1 Bound \\
\cline { 2 - 5 } $\mathrm{k}-6$ & $10 \%$ & 2.12 & 3.23 \\
\cline { 2 - 5 } & $5 \%$ & 2.45 & 3.61 \\
\cline { 2 - 5 } & $1 \%$ & 3.15 & 4.43 \\
\hline
\end{tabular}

Source: Authors' calculation using Eviews 
After having confirmed the co-integrating relation, next step is to estimate the long run and short run elasticities. Results are explained in Table 6 and 7. As log linear model has been taken into consideration for our study, relationships will be discussed by elasticity. In the long run, inequality rises by 0.08 percent for a percentage increase in Export. In other words, export earning amplifies the inequality. It is consistent with Malvikas' (2016) work. Over last three decades export performance of Bangladesh is quite impressive and it shows an upward trend. The industry which reshaping and rebuilding the economy of Bangladesh is none other than readymade garments (RMG) industry which has become the biggest export earner in recent years. The sectors earn almost $80 \%$ of export earnings alone. But it has been noticed that most of the labor in this sector can’t attain a subsistent level of wage ( $\$ 4$ in a day) even after so many unprecedented improvements of RMG industries. The owner grabs the lion share of profit which is the core reason behind the positive relationship between export and income inequality (Mahmood, 2020).

On the other hand, if import increases by 1 percent, inequality decreases by $0.05 \%$. But the relationship is insignificant. As a developing country Bangladesh needs to meet her needs and necessity by importing goods from abroad like China, India, and Japan etc. But in the case of import, Bangladesh has to pay much higher tariff which is the highest (25.6\%) among ASEAN nation. People therefore have to spend higher price than world price for buying consumable goods. So, Government of Bangladesh took necessary initiative to establish import substitution industry. After setting up some of those infant industries, a few employment opportunities are created which may reduce the income inequality gap, but the number of infant industry is not adequate enough to lessen the wider gap of income disparity. That's why we face an insignificant relation between income inequalities and import (Sattar, 2018). This result is similar to Fredriksson (2014).

All of our variables are significant in the long run except import. Per capita GDP, remittance and exchange rate reduces the income gap of the county. The sign with per capita income follows the conventional thinking which is similar to Malvika (2016), Olofade (2012) and Aigheyisi \& Egbon (2020). As we know, per capita GDP is one of the most effective ways of measuring average living standard, prosperity and development of a nation. So, it can be concluded that rising per capita GDP minimize the gap by influencing income of mass people. The coefficient for Urbanization is negative. The more people migrate toward the urban area, the more the income becomes uneven. Because more city-centric working environment may be created by this (Munir, 2013; Atif et al., 2012). The increase in remittance earnings tends to reduce income gap. According to UNDP, almost 10 million migrants workers at abroad and which is increasing by 4 lakhs every year. They also provide us a vast amount of remittance flow which helps to generate income of mass people. That's the reason of the sign of remittance coefficient which is supported by Amjad (2015) \& Arif \& Saeduzzaman (2015). Exchange rate is negatively associated with Gini coefficient. The exporter gets some extra benefit when exchange rate devaluation occurs which increase the export earnings. The result is opposite to Malvika (2016). 
Table 6. Long Run Coefficients

\begin{tabular}{|l|l|l|l|}
\hline \multicolumn{4}{|l|}{ Dependent variable: Gini } \\
ARDL $(1,1,1,2,0,0,1)$ based on Akaike information criterion (AIC) \\
\hline Variable & Coefficient & Std. Error & t-statistic \\
\hline Exp & $0.08^{* * *}$ & 0.028631 & 2.794274 \\
\hline Imp & -0.05 & 0.052025 & -0.990992 \\
\hline PcG & $-0.13^{* * *}$ & 0.038552 & -3.353003 \\
\hline Ur & $0.42^{* * *}$ & 0.137590 & 3.054287 \\
\hline Rem & $-0.04^{* *}$ & 0.018559 & -2.158127 \\
\hline Exg & $-0.18^{* *}$ & 0.073436 & -2.468819 \\
\hline Constant & -1.94 & 1.548095 & -1.254774 \\
\hline $\begin{array}{l}* * 1 \% \text { significance level } \\
* * 5 \% \text { significance level }\end{array}$ & \\
\hline
\end{tabular}

Source: Authors' calculation using Eviews

Table 7. Short Run Coefficients

\begin{tabular}{|c|c|c|c|}
\hline \multicolumn{4}{|c|}{ Dependent variable: $\triangle$ Gini } \\
\hline Variable & Coefficient & Std. Error & t-statistic \\
\hline$\triangle \operatorname{Exp}$ & $0.009^{* *}$ & 0.003568 & 2.483518 \\
\hline$\triangle \operatorname{Imp}$ & $-0.01^{*}$ & 0.005859 & -1.955411 \\
\hline$\triangle \mathrm{PcG}$ & -0.008 & 0.009499 & -0.833596 \\
\hline$\triangle \mathrm{PcG}(-1)$ & $-0.009^{* *}$ & 0.004103 & -2.195964 \\
\hline$\triangle$ Rem & $-0.006^{* *}$ & 0.002476 & -2.538636 \\
\hline$\triangle \mathrm{Ur}$ & $-0.07^{* * *}$ & 0.015041 & 4.384742 \\
\hline$\triangle \operatorname{Exg}$ & $-0.02^{*}$ & 0.012437 & -1.730982 \\
\hline Ect & $-0.16^{\text {**** }}$ & \begin{tabular}{|l|l}
0.048160 \\
\end{tabular} & -3.258593 \\
\hline \multicolumn{4}{|c|}{$\begin{array}{l}* * * 1 \% \text { Significance level } \\
* * 5 \% \text { Significance level } \\
* 10 \% \text { Significance level }\end{array}$} \\
\hline
\end{tabular}

Source: Authors' calculation using Eviews

After that short run dynamics should be explained. In table 7, coefficient of error correction term is negative and significant at $1 \%$ level. It implies that disequilibrium in income inequality will be corrected and converged to the long run equilibrium at a speed of $16 \%$. Moreover, in the short run almost all of the elasticities are significant and in line with the long run relations and theory as well. Table 8 represents various diagnostic tests which have been inspected regarding the ARDL results. None of the null hypothesis of our diagnostic test has been rejected as every probability value $\mathrm{p}$ is greater than $5 \%$ threshold level (Note 3 ). As 


\section{I Macrothink}

Business and Economic Research ISSN 2162-4860 2021, Vol. 11, No. 3

a result it is certain that the error terms are not correlated and they are homoscedastic. Furthermore, the white noise error terms are random and normally distributed. Moreover, our estimated model is correctly specified and there is no omitted variable bias in the functional form.

Table 8. Diagnostic test

\section{Breusch-Godfrey Serial Correlation LM test}

\begin{tabular}{ll|ll}
\hline F-Statistic: & 0.698308 & Prob. F(2,25) : & 0.5069 \\
Obs*R-squared: & 2.116355 & Prob. Chi-Square(2): & 0.3471 \\
\hline
\end{tabular}

Heteroscedasticity Test: Breusch-Pagan-Godfrey

\begin{tabular}{|lc|lc|}
\hline F-statistic: & 0.291019 & Prob. F(12,27) : & 0.9858 \\
Obs*R-squared: & 4.581136 & Prob. Chi-Square(12): & 0.9705 \\
\hline Normality test: Jarque-Bera test & & \\
\hline J-B: & 1.247760 & Prob. : & 0.535861 \\
\hline Ramsey RESET test & & 0.4834 \\
\hline t-statistics : & 0.711100 & Prob. : & 0.4834 \\
F-statistics : & 0.505663 & Prob. : &
\end{tabular}

Source: Authors' calculation using Eviews

Figure 1 and 2 embodies the results of CUSUM and CUSUM square test. The red lines delineate critical bands of $5 \%$ confidence interval. From both figures it is obvious that none of estimated blue lines exceed the critical red lines. Hence all the parameters regarding the study are stable and there is no structural change over the sample period.

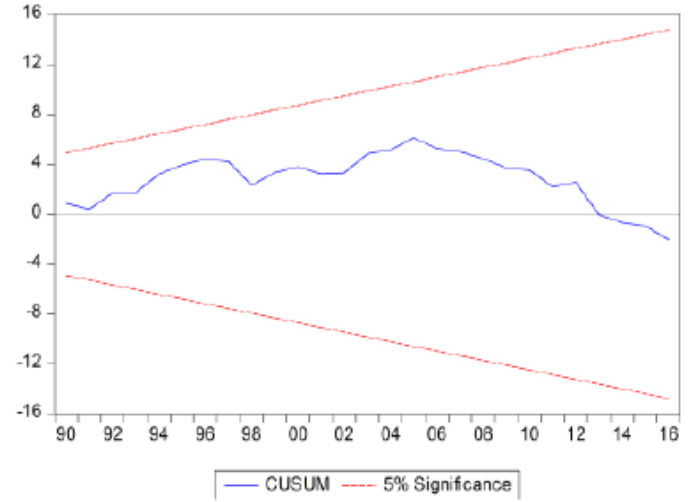

Figure 1. CUSUM test

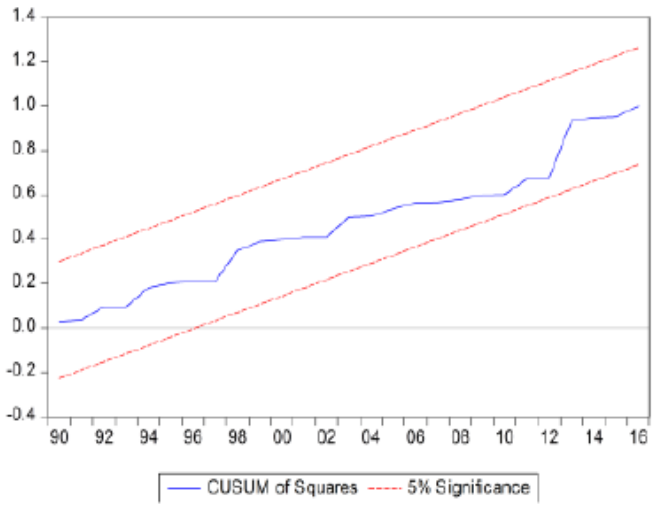

Figure 2. CUSUM square test

For checking robustness FMOLS, DOLS and CCR have been used in this study. The expected sign and significance of Exp is consistent with FMOLS, DOLS and CCR. No matter what it poses different signs, import has been insignificant in all estimations along with ARDL. However, almost all of the estimators of ARDL are in line with table 8 results except exchange rate. Exchange rate has significantly reduced inequality in ARDL model but turns 
insignificant in other models. So coefficients from ARDL model can be declared vigorous and reliable as most of them are consistent with the results of table 9.

Table 9. Long run robustness check

\begin{tabular}{|l|l|l|l|}
\hline Variable & FMOLS & DOLS & CCR \\
\hline Exp & $0.044^{* * *}(3.208160)$ & $0.04(1.655293)$ & $0.05^{* *}(2.379069)$ \\
\hline Imp & $0.04(1.646386)$ & $0.03(1.030997)$ & $0.04(1.438867)$ \\
\hline PcG & $-0.12^{* * *}(-5.783808)$ & $-0.14^{* * *}(-6.360185)$ & $-0.13^{* * *}(-4.814042)$ \\
\hline Rem & $-0.02^{*}(-1.881657)$ & $-0.02^{* *}(-2.642967)$ & $-0.02^{* *}(-2.213068)$ \\
\hline Ur & $0.14^{* * *}(2.689271)$ & $0.21^{* * *}(3.629185)$ & $0.14^{* *}(2.173107)$ \\
\hline Exg & $-0.04(-1.191435)$ & $-0.03(-0.912888)$ & $-0.05(-1.450018)$ \\
\hline $\mathrm{C}$ & $0.62(0.944791)$ & $-0.21(-0.270213)$ & $0.62(0.733455)$ \\
\hline $\mathrm{R}^{2}$ & 0.970427 & 0.999041 & 0.970655 \\
\hline Adj. $\mathrm{R}^{2}$ & 0.965050 & 0.997269 & 0.965319 \\
\hline S.E. of regression & 0.008938 & 0.002489 & 0.008904 \\
\hline $\begin{array}{l}\text { Note: t-statistics are given in parenthesis }() . * * *, * * \text { and } \\
* \text { denote level of significance at } 1 \% 5 \% \text { and } 10 \% \text { level. }\end{array}$ \\
\hline
\end{tabular}

Source: Authors' calculation using Eviews

\section{Conclusion}

This study inspected impact of export and import on income inequality in Bangladesh for the time period of 1975 to 2016 by using ARDL. The presence of co-integrating relationship is confirmed by applying Bound test. The result shows, export earning broadens the inequality gap in the long run period as it is positively and significantly related to income inequality. On the other hand, import fails to exhibit any substantial relations because of inadequate number of import substitution. Empirical findings from this study suggest a refinement of existing policies in this regard by discerning the current national socio-economic situation and dynamics of world trade. However switching, reforming and adopting policy is treated as precondition for leveling the gap on the field of inequality. Government should impose tax according to the ability to pay of a man's income and property such as putting on progressive tax (tax rate which increases as income increases) on rich person. In order to influence the domestic production, government should impose more tariffs on those imported goods which can be substituted by local producer. But in the era of free trade it is quite tough to increase more barriers on import. So, import substitution is required. Subsidy should be bestowed to those who have potentialities to create import substitution. As we already have noticed that our export is limited to a few sectors like RMG, Leather, Frozen Fish \& Jute products etc. If a crisis arises on any of these, our economy will experience a massive change. So, in order to reduce the dependency of those sectors, government should take initiative to establish some efficient branch such as handicrafts, cottage industry, pharmaceutical by which we can export additional differentiated products into world market which may helpful to generate some employment opportunity to the rural and disadvantaged people. And easy loan should be 
introduced.

According to a report of ILO, almost 30 million educated people are unemployed in Bangladesh. The core reason is lacking of proper practical \& technical knowledge. So, government should definitely invest more on vocational education. After receiving necessary knowledge, those young generations will transformed into human capital, will invent new technique to expand more exportable sectors.

In order to lessen income inequality, government and international organization should work together. In developing country, it's a common scenery that a few large firms get more chances of exporting goods in abroad, because they get an advantages of having a large number of capital, visible infrastructure and well performed officials, attracts more foreign buyers which stimulate them to produces maximum amount of exporting products . Beside that small medium entrepreneur often deprive of taking the chance of graving the market because of asymmetric information, smaller amount of worker, fewer amounts of capital and inadequate knowledge about processing and marketing. So, dominant firms capture the lion share of export earnings. For this reason, income disparity creates between large and small firm. So, equal opportunities need to be ensured for all type of firms. International organization like WTO, EU, and SAARC etc. should ensure transparency, information and accountability for all. "Aid for trade" can be a better option for small and medium exporter of the poor country, reported by UNCTAD (2019).

\section{Declaration of Conflicting Interests}

The Author(s) declare(s) that there is no conflict of interest.

\section{Funding}

This research received no specific grant from any funding agency in the public, commercial, or not-for-profit sectors.

\section{ORCID iD:}

1. Munem Ahmad Chowdhury: 0000-0002-0876-0771

2. Hafsa Rahman Nijhum : 0000-0003-1786-8618

\section{References}

Adams, S. (2008). Globalization and income inequality: Implications for intellectual property rights. Journal of Policy Modeling, 30(5), 725-735.

https://doi.org/10.1016/j.jpolmod.2007.10.005

Aigheyisi, O. S., \& Egbon, H. O. (2020). Effect of FDI on Income Inequality in Nigeria: Does Trade Openness Matter? Journal of Academic Research in Economics, 12(2), 336-346.

Aigheyisi, O. S., \& Egbon, H. O. (2020). Effect of FDI on Income Inequality in Nigeria: Does Trade Openness Matter? Journal of Academic Research in Economics, 12(2). 336-346.

Amjad, Z. (2015). Trade and Income Distribution in Pakistan. Global Journal of Management 
and Business Research: Economics and Commerce, 15(8), 18-25.

Anderson, E. (2005). Openness and inequality in developing countries: A review of theory and recent evidence. World development, 33(7), 1045-1063.

https://doi.org/10.1016/j.worlddev.2005.04.003

Aradhyula, S., Rahman, T., \& Seenivasan, K. (2007). Impact of international trade on income and income inequality. Paper presented at American Agricultural Economics Association Annual Meeting, Portland.

Arif, K. M., Saeduzzaman, A., \& Student, M. (2015). Economic Globalization and Income Inequality in Bangladesh. Bangladesh Journal of Political Economy, 31(2), 115.

Atif, S. M., Srivastav, M., Sauytbekova, M., \& Arachchige, U. K. (2012). Globalization and Income Inequality: A Panel Data Analysis of 68 Countries. MPRA Paper No. 42385, Munich University Library.

Bahmani-Oskooee, M., \& Brooks, T. J. (2003). A new criteria for selecting the optimum lags in Johansen's cointegration technique. Applied Economics, 35(8), 875-880.

https://doi.org/10.1080/00036840210129419

Barro, R. J. (2000). Inequality and Growth in a Panel of Countries. Journal of economic growth, 5(1), 5-32. https://doi.org/10.1023/A:1009850119329

Barusman, A. F., \& Barusman, M. Y. S. (2017). The Impact of International Trade on Income Inequality in the United States since 1970's. European Research Studies Journal, XX(4), 35-50. https://doi.org/10.35808/ersj/818

BBS. (2016). Statistical Yearbook of Bangladesh. Dhaka: Bangladesh Bureau of Statistics.

Brown, R. L., Durbin, J., \& Evans, J. M. (1975). Techniques for testing the constancy of regression relationships over time. Journal of the Royal Statistical Society: Series B (Methodological), 37(2), 149-163. https://doi.org/10.1111/j.2517-6161.1975.tb01532.x

Bukhari, M., \& Munir, K. (2016). Impact of Globalization on Income Inequality in Selected Asian Countries. MPRA Paper No. 74248, Munich University Library.

Calderón, C., \& Chong, A. (2001). External sector and income inequality in interdependent economies using a dynamic panel data approach. Economics letters, 71(2), 225-231. https://doi.org/10.1016/S0165-1765(01)00374-3

Daumal, M. (2013). The impact of trade openness on regional inequality: the cases of India and Brazil. The International Trade Journal, 27(3), 243-280.

https://doi.org/10.1080/08853908.2013.796839

Dickey, D. A., \& Fuller, W. A. (1979). Autoregressive time series with a unit root. Journal of the American statistical association, 74(366), 427-431.

https://doi.org/10.1080/01621459.1979.10482531

Fredriksson, G. (2014). A Detailed Analysis of International Trade and Income Inequality in 
Developed Countries (Unpublished Bachelor's thesis). Erasmus University Rotterdam.

Gourdon, J. (2007). Trade and Wage Inequality in Developing Countries: South-South Trade Matter, Working Papers 200710, CERDI.

Gujarati, D. N., Porter, D. C., \& Gunasekar, S. (2012). Basic econometrics. Tata McGraw-Hill Education.

Jaumotte, F., Lall, S., \& Papageorgiou, C. (2013). Rising income inequality: technology, or trade and financial globalization? IMF Economic Review, 61(2), 271-309.

https://doi.org/10.1057/imfer.2013.7

Khan, I., Nawaz, Z., \& Saeed, B. B. (2020). Does trade openness and FDI reduce inequality? Evidence from South Asia. International Journal of Finance \& Economics. 1-12. https://doi.org/10.1002/ijfe.2131

Khan, R. E. A., \& Bashir, N. (2011). Trade Liberalization, Poverty and Inequality Nexus: A Case Study of India. Asian Economic and Financial Review, 1(3), 114-119.

Lim, G., \& McNelis, P. D. (2014). Income Inequality, Trade and Financial Openness. RES-SPR Conference on Macroeconomic Challenges Facing. Washington: International Monetary Fund. https://doi.org/10.2139/ssrn.2425068

Lundberg, M., \& Squire, L. (2003). The simultaneous evolution of growth and inequality. The economic journal, 113(487), 326-344. https://doi.org/10.1111/1468-0297.00127

MacKinnon, J. G. (1991). Critical values for cointegration tests. In R. F. Engle \& C. W. J. Granger (Eds.), Long-run Economic Relationships: Readings in Cointegration (pp. 267-276). Oxford, United Kingdom: Oxford University Press.

Mahesh, M. (2016). The effects of trade openness on income inequality-evidence from BRIC countries. Economics Bulletin, 36(3), 1751-1761.

Mahmood, M. (2020, October 10). Trade and income inequality in Bangladesh. The Financial Express. [Online] Available:

https://thefinancialexpress.com.bd/views/trade-and-income-inequality-in-bangladesh-160234 5030

Masih, R., \& Masih, A. M. (1996). Stock-Watson dynamic OLS (DOLS) and error-correction modelling approaches to estimating long-and short-run elasticities in a demand function: new evidence and methodological implications from an application to the demand for coal in mainland China. Energy Economics, 18(4), 315-334.

https://doi.org/10.1016/S0140-9883(96)00016-3

Meschi, E., \& Vivarelli, M. (2009). Trade and income inequality in developing countries. World development, 37(2), 287-302.

https://doi.org/10.1016/j.worlddev.2008.06.002

Muhibbullah, M., \& Das, M. R. (2019). The Impact of Inflation on the Income Inequality of Bangladesh: A Time Series Analysis. International Journal of Business and 
Technopreneurship, 9(2), 141-150.

Munir, S., Kiani, A. K., Khan, A., \& Jamal, A. (2013). The Relationship between Trade Openness and Income Inequalities Empirical Evidences from Pakistan (1972-2008). Academic Journal of Management Sciences, 2(1), 21-35.

Narayan, P. K. (2005). The saving and investment nexus for China: evidence from cointegration tests. Applied economics, 37(17), 1979-1990.

https://doi.org/10.1080/00036840500278103

Nath, H., \& Al Mamun, K. A. (2004). Trade Liberalization, Growth and Inequality in Bangladesh: An Empirical Analysis. In This paper was presented at the 41st Annual Conference of the Missouri Valley Economic Association held in October. [Online] Available: http:// www .shsu.edu/ eco_hkn/hiranya_wip3.pdf

Oloufade, D. K. (2012). Trade Openness, Conflict Risk and Income Inequality. MPRA Paper No. 40702, Munich University Library. https://doi.org/10.2139/ssrn.2135222

Park, J. Y. (1992). Canonical cointegrating cegressions. Econometrica, 60(1), 119-143. https://doi.org/10.2307/2951679

Pesaran, M. H., Shin, Y., \& Smith, R. J. (2001). Bounds testing approaches to the analysis of level relationships. Journal of applied econometrics, 16(3), 289-326.

https://doi.org/10.1002/jae.616

Phillips, P. C., \& Hansen, B. E. (1990). Statistical inference in instrumental variables regression with I (1) processes. The Review of Economic Studies, 57(1), 99-125. https://doi.org/10.2307/2297545

Priyankara, E. A. C. (2018). The long-run effect of services exports on total factor productivity growth in Sri Lanka: Based on ARDL, FMOLS, CCR, and DOLS approaches. International Journal of Academic Research in Business and Social Sciences, 8(6), 233-253. https://doi.org/10.6007/IJARBSS/v8-i6/4180

Sapuan, N. M., \& Roly, M. R. (2020). Oil Abundance and Human Capital in Malaysia: A Multivariate Cointegration Analysis. International Journal of Energy Economics and Policy, 10(3), 303-310. https://doi.org/10.32479/ijeep.8578

Sattar, Z. (2018, July 01). The costs of industrial protection: who pays? The Daily Star. [Online] Available:

https://www.thedailystar.net/business/the-costs-industrial-protection-who-pays-1597954

Shahbaz, M., \& Rahman, M. M. (2010). Foreign capital inflows-growth nexus and role of domestic financial sector: an ARDL co-integration approach for Pakistan. Journal of Economic Research, 15(3), 207-231.

Siddiqui, M. S. (2019, November 09). Mismatch between import liberalisation and export competitiveness. The Financial Express. [Online] Available:

https://www.thefinancialexpress.com.bd/views/mismatch-between-import-liberalisation-and- 
export-competitiveness-1573308695

Stock, J. H., \& Watson, M. W. (1993). A simple estimator of cointegrating vectors in higher order integrated systems. Econometrica: Journal of the Econometric Society, 61(4), 783-820. https://doi.org/10.2307/2951763

UNCTAD. (2019). Trade policies for combating inequality: Equal opportunities to firms, workers and countries. United Nations Publications, New York: UNCTAD. [Online] Available: https://unctad.org/system/files/official-document/ditctab2019d6_en.pdf.

Wooldridge, J. M. (2010). Econometric analysis of cross section and panel data. MIT press.

\section{Notes}

Note 1. ARDL doesn't take second difference in consideration because it may provide spurious result for this dynamic approach.

Note 2. Where $\mathrm{P}$ and $\mathrm{k}$ denote lag length and number of variables.

Note 3. Null hypothesis of these tests are, Breusch-Godfrey: $\mathrm{H} 0=$ there is no serial correlation; Breusch-Pagan-Godfrey: $\mathrm{HO}=$ there is no heteroscedasticity in error terms; Jarque-Bera: $\mathrm{HO}=$ residuals are normally distributed; Ramsey RESET test: $\mathrm{H} 0=$ the model is not misspecified.

\section{Copyright Disclaimer}

Copyright for this article is retained by the author(s), with first publication rights granted to the journal.

This is an open-access article distributed under the terms and conditions of the Creative Commons Attribution license (http://creativecommons.org/licenses/by/4.0/). 